\title{
Spironolactone, a Classic Potassium-Sparing Diuretic, Reduces Survivin Expression and Chemosensitizes Cancer Cells to Non-DNA-Damaging Anticancer Drugs
}

\author{
Tomomi Sanomachi ${ }^{1,2,+}$, Shuhei Suzuki ${ }^{1,2,+}$, Keita Togashi ${ }^{1,3}$, Asuka Sugai ${ }^{1}$, Shizuka Seino ${ }^{1}$, \\ Masashi Okada ${ }^{1}$, Takashi Yoshioka ${ }^{2}$, Chifumi Kitanaka ${ }^{1,4}$ and Masahiro Yamamoto ${ }^{1, *(D)}$ \\ 1 Department of Molecular Cancer Science, Yamagata University School of Medicine, 2-2-2 Iida-nishi, \\ Yamagata 990-9585, Japan; t-sanomachi@med.id.yamagata-u.ac.jp (T.S.); \\ s-suzuki@med.id.yamagata-u.ac.jp (S.S.); ke-togashi@med.id.yamagata-u.ac.jp (K.T.); \\ s-asuka@med.id.yamagata-u.ac.jp (A.S.); s.sizuka@med.id.yamagata-u.ac.jp (S.S.); \\ m-okada@med.id.yamagata-u.ac.jp (M.O.); ckitanak@med.id.yamagata-u.ac.jp (C.K.) \\ 2 Department of Clinical Oncology, Yamagata University School of Medicine, 2-2-2 Iida-nishi, \\ Yamagata 990-9585, Japan; ytakashi@med.id.yamagata-u.ac.jp \\ 3 Department of Ophthalmology and Visual Sciences, Yamagata University School of Medicine, \\ 2-2-2 Iida-nishi, Yamagata 990-9585, Japan \\ 4 Research Institute for Promotion of Medical Sciences, Yamagata University Faculty of Medicine, \\ 2-2-2 Iida-nishi, Yamagata 990-9585, Japan \\ * Correspondence: masahiro@med.id.yamagata-u.ac.jp; Tel.: +81-23-628-5214 \\ + These authors equally contributed to the work.
}

Received: 26 August 2019; Accepted: 10 October 2019; Published: 14 October 2019

\begin{abstract}
Spironolactone, a classical diuretic drug, is used to treat tumor-associated complications in cancer patients. Spironolactone was recently reported to exert anti-cancer effects by suppressing DNA damage repair. However, it currently remains unclear whether spironolactone exerts combinational effects with non-DNA-damaging anti-cancer drugs, such as gemcitabine and epidermal growth factor receptor tyrosine kinase inhibitors (EGFR-TKIs). Using the cancer cells of lung cancer, pancreatic cancer, and glioblastoma, the combinational effects of spironolactone with gemcitabine and osimertinib, a third-generation EGFR-TKI, were examined in vitro with cell viability assays. To elucidate the underlying mechanisms, we investigated alterations induced in survivin, an anti-apoptotic protein, by spironolactone as well as the chemosensitization effects of the suppression of survivin by YM155, an inhibitor of survivin, and siRNA. We also examined the combinational effects in a mouse xenograft model. The results obtained revealed that spironolactone augmented cell death and the suppression of cell growth by gemcitabine and osimertinib. Spironolactone also reduced the expression of survivin in these cells, and the pharmacological and genetic suppression of survivin sensitized cells to gemcitabine and osimertinib. This combination also significantly suppressed tumor growth without apparent adverse effects in vivo. In conclusion, spironolactone is a safe candidate drug that exerts anti-cancer effects in combination with non-DNA-damaging drugs, such as gemcitabine and osimertinib, most likely through the suppression of survivin.
\end{abstract}

Keywords: drug resistance; spironolactone; osimertinib; survivin; xenograft; cancer stem cells

\section{Introduction}

Cancer is one of the most common causes of death [1]. The development of therapeutic strategies for patients with advanced cancer has markedly improved overall survival. However, 
resistance to anticancer reagents is inevitable, and the prognosis of advanced cancer remains poor. There are several potential sources of chemoresistance, including alterations to drug transporters, the suppression of apoptosis, mitochondrial alterations, the promotion of DNA damage repair, autophagy, epithelial-mesenchymal transition, and cancer stem cells (CSCs) [2-6]. Appropriate chemotherapeutic strategies that consider the mechanisms of resistance are necessary to cure cancer.

Non-small cell lung cancer (NSCLC), pancreatic cancer, and glioblastoma are malignancies with poor prognoses [7], and improvements in treatments for these malignancies are awaited. Gemcitabine $\left(2^{\prime}, 2^{\prime}\right.$-difluorodeoxycytidine, $\left.\mathrm{dFdC}\right)$ is a pyrimidine nucleotide antimetabolite that is incorporated into DNA and terminates DNA replication. It is one of the standard chemotherapeutic reagents for solid tumors, including NSCLC and pancreatic cancer [8,9]. However, the effects of gemcitabine on NSCLC and pancreatic cancer are limited due to resistance [10,11]. Epidermal growth factor receptor (EGFR) signaling is activated in several types of solid cancer, including NSCLC, pancreatic cancer, and glioblastoma [12,13]. Thus, EGFR is a candidate target for molecular-targeted therapy for these types of cancers. However, the clinical benefits of first- and second-generation EGFR tyrosine kinase inhibitors (EGFR-TKIs) are limited in NSCLC, pancreatic cancer, and glioblastoma due to drug resistance [14-21]. For example, a phase III trial demonstrated that the combination of erlotinib, a first-generation EGFR-TKI, and gemcitabine improved the survival of patients with advanced pancreatic cancer; however, this improvement was limited [15]. In glioblastoma, clinical trials on EGFR-TKIs, such as gefitinib, erlotinib, and dacomitinib, demonstrated that their clinical benefits were limited or absent [18-21]. Osimertinib, a third-generation EGFR-TKI, was developed to overcome the EGFR-TKI-resistant T790M mutation in the EGFR gene that is frequently acquired during treatments with standard EGFR-TKIs for NSCLC [22,23]. Osimertinib is superior to standard EGFR-TKIs as first-line therapy for NSCLC [24]; however, resistance occurs, which limits its efficacy [25]. Furthermore, since the safety profile of osimertinib was found to be better than those of other standard EGFR-TKIs in clinical trials $[23,24]$, it is one of the promising drugs for the treatment of pancreatic cancer and glioblastoma. Strategies that augment the effects of anticancer drugs, such as gemcitabine and osimertinib, are needed to improve the prognosis of these malignancies.

Drug repositioning or repurposing is a method that applies already-approved drugs to new indications [26,27]. The development of new drugs de novo is not only time-consuming and expensive, the success rate for drug approval is low [28]. All phases of clinical trials have been completed for already-approved drugs, and their safety profiles in humans are known. Thus, drug repositioning saves the time and costs associated with drug development and is attracting increasing interest by academia and industries. Drug repositioning has been successfully applied to several drugs. For example, finasteridine and minoxidil, which were originally developed to treat benign prostatic hyperplasia and hypertension, respectively, are now utilized for androgenic alopecia [29]. In the field of cancer therapy, non-oncological drugs are now being applied to the treatment of cancer: thalidomide, an anti-emetic drug, is now applied to the treatment of multiple myeloma [30], and everolimus, originally developed as an immunosuppressant, is used in the treatment of breast cancer, renal cell carcinoma, and neuroendocrine tumors [31-34].

Spironolactone, a classic potassium-sparing diuretic drug, is used to treat ascites in patients with cancer [35], hypertension derived from an adverse effect of anti-angiogenesis drugs [36,37], and brain edema caused by brain tumors [38]. Thus, spironolactone is a well-tolerated drug even in patients with cancer. Recent studies reported that spironolactone exerts anticancer effects by suppressing DNA damage repair and acts as a chemosensitizer in combination with DNA-damaging reagents, such as cisplatin [39-41]. Therefore, spironolactone is a good candidate drug for cancer therapy from the perspective of drug repositioning. However, it currently remains unclear whether spironolactone acts as a chemosensitizer of anticancer reagents that do not involve DNA damaging. In the present study, we examined the anticancer effects of spironolactone combined with gemcitabine and osimertinib, which are not DNA-damaging reagents, in non-stem cancer cells and the CSCs of NSCLC, pancreatic 
cancer, and glioblastoma in vitro and in vivo and investigated the mechanisms responsible for these anticancer effects.

\section{Results}

\subsection{Spironolactone Inhibits Cancer Cell Growth and Is Cytotoxic to Cancer Cells, including CSCs, but not to} Normal Cells

To examine whether spironolactone exerts cancer cell growth inhibitory effects, three representative cancer cell lines (A549, PANC-1, and PC-9) and one subline (PC-9-OR; osimertinib-resistant PC-9) were treated with spironolactone, and then subjected to cell viability assays. Spironolactone induced cell death and inhibited growth in these cell lines (Figure 1a and Figure S1). We then examined whether spironolactone exerts inhibitory effects on CSC lines. We treated two representative CSCs (A549 CSLC and PANC-1 CSLC cells) with spironolactone and then subjected them to cell viability assays. Spironolactone induced cell death and inhibited growth in CSCs (Figure 1b). We also examined the toxicity of spironolactone in non-cancer cells. We treated non-cancer cells (normal human fibroblasts [IMR-90]) with spironolactone, and then subjected them to cell viability assays. Spironolactone was not toxic to normal cells at the concentrations examined (Figure 1c). These results imply that spironolactone is not toxic to normal cells, but exerts cancer cell- and CSC-specific cytotoxic and growth inhibitory effects.
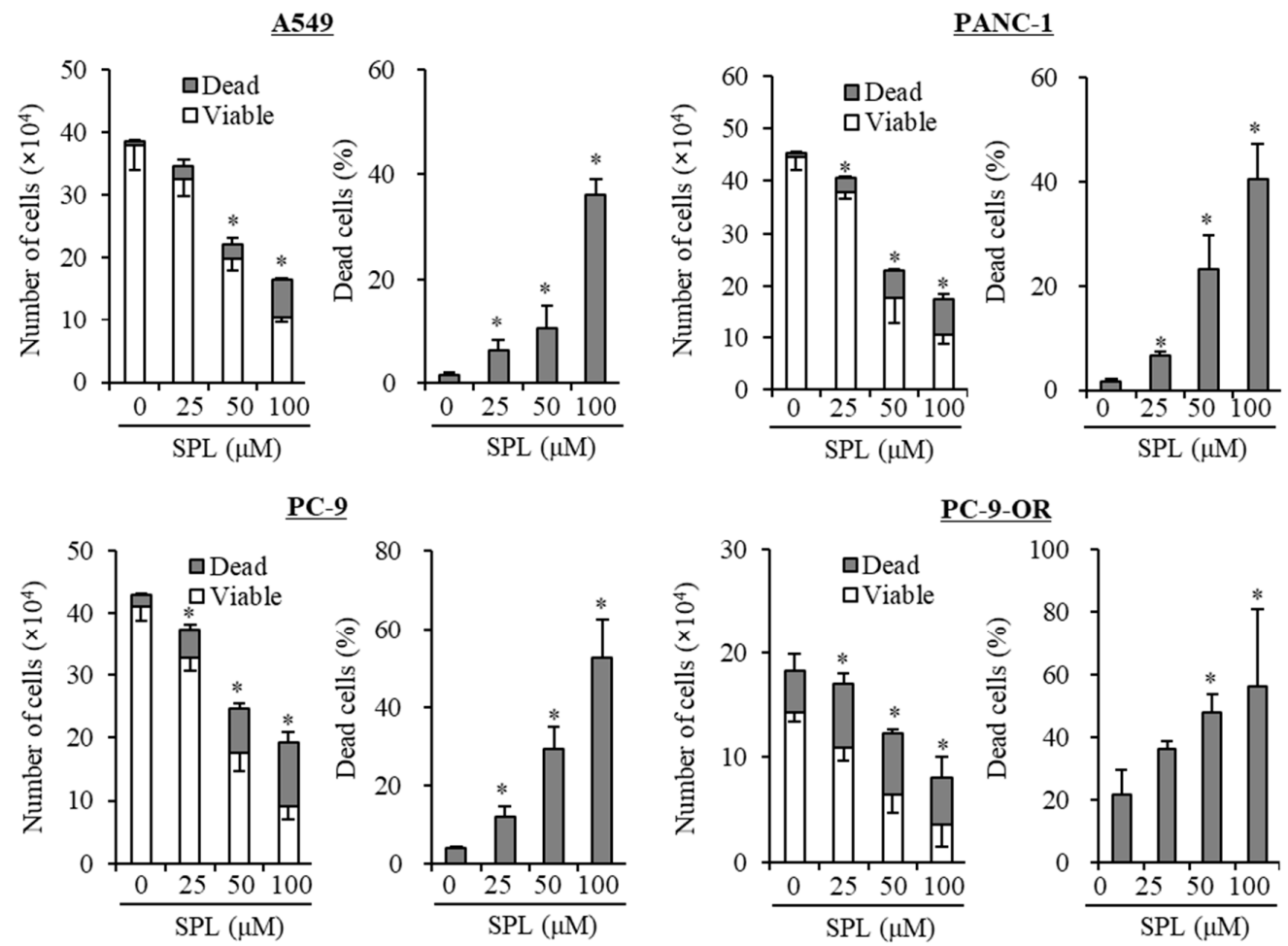

(a)

Figure 1. Cont. 
A549 CSLC
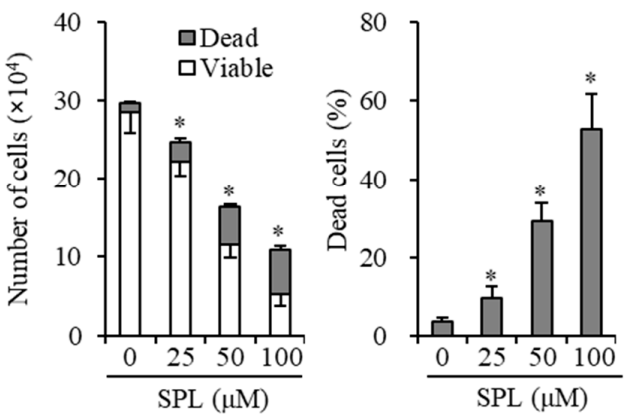

PANC-1 CSLC

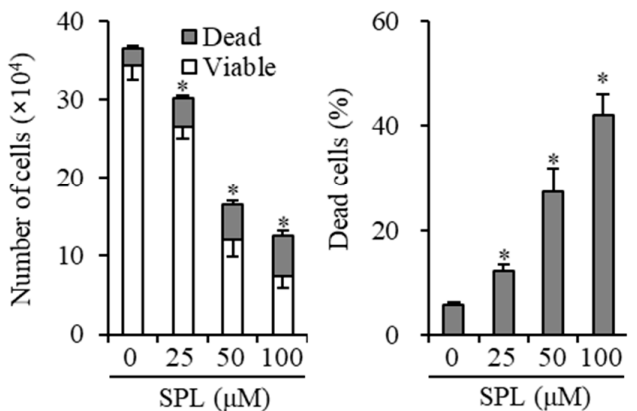

(b)

$\underline{\text { IMR-90 }}$

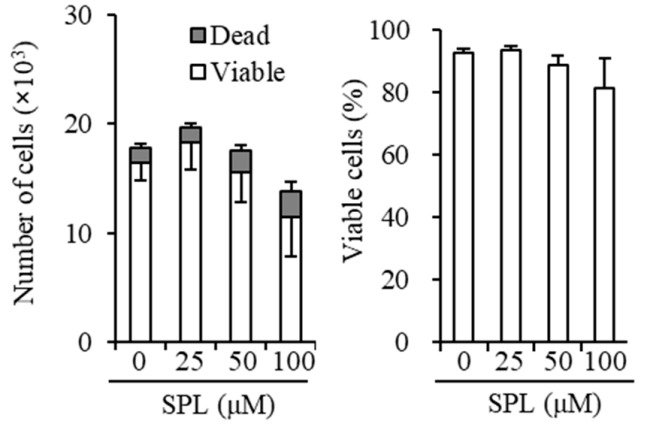

(c)

Figure 1. Spironolactone selectively induces cell death and inhibits the growth of cancer cells. A549, PANC-1, PC-9, and PC-9-OR (osimertinib-resistant) (a), cancer stem cell lines (A549 CSLC and PANC-1 CSLC) (b), and IMR90 normal human fibroblasts (c) were treated without (as control) or with the indicated concentrations of spironolactone (SPL) for three days, and the numbers of viable and dead cells (left panels) as well as the percentage of dead cells (right panels) were then assessed. Values in the graphs represent the means \pm SD of triplicate samples of a representative experiment repeated with similar results. ${ }^{*} p<0.05$.

\subsection{Spironolactone Decreases Resistance to Gemcitabine and Osimertinib}

To examine whether spironolactone reduces resistance to anticancer reagents, A549, PANC-1, PC-9, and PC-9-OR cell lines were co-treated with spironolactone and an anticancer reagent, gemcitabine or osimertinib, and these treated cells were then subjected to cell viability assays. The results obtained showed that spironolactone reversed resistance to these anticancer reagents (Figure 2).

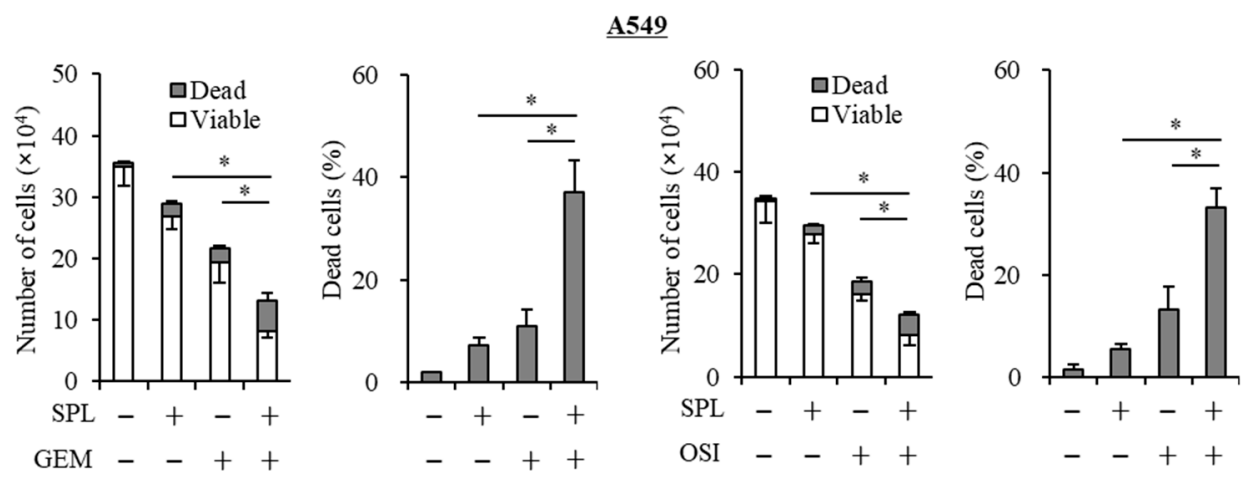

Figure 2. Cont. 

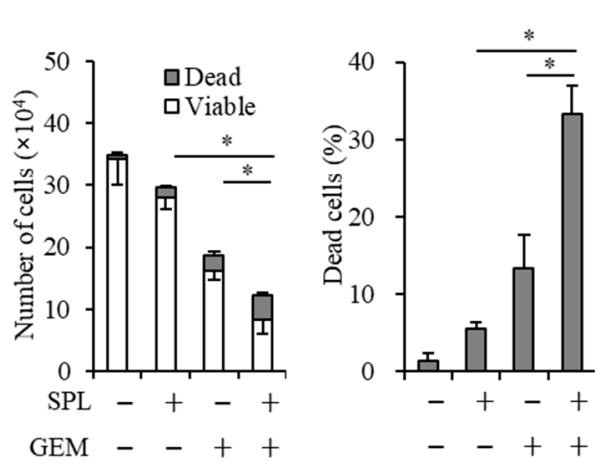

\section{PANC-1}
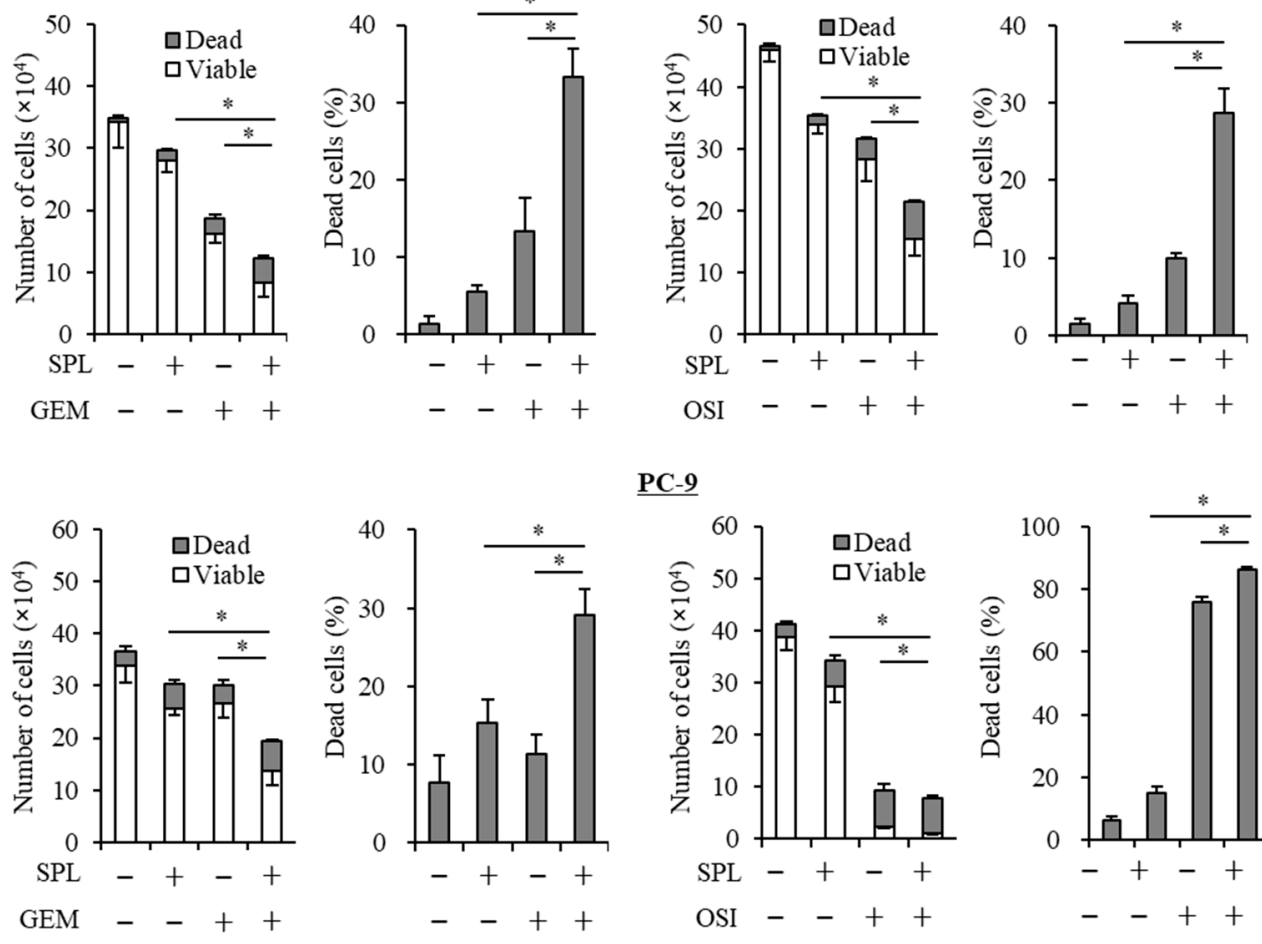

$\underline{\text { PC-9 }}$
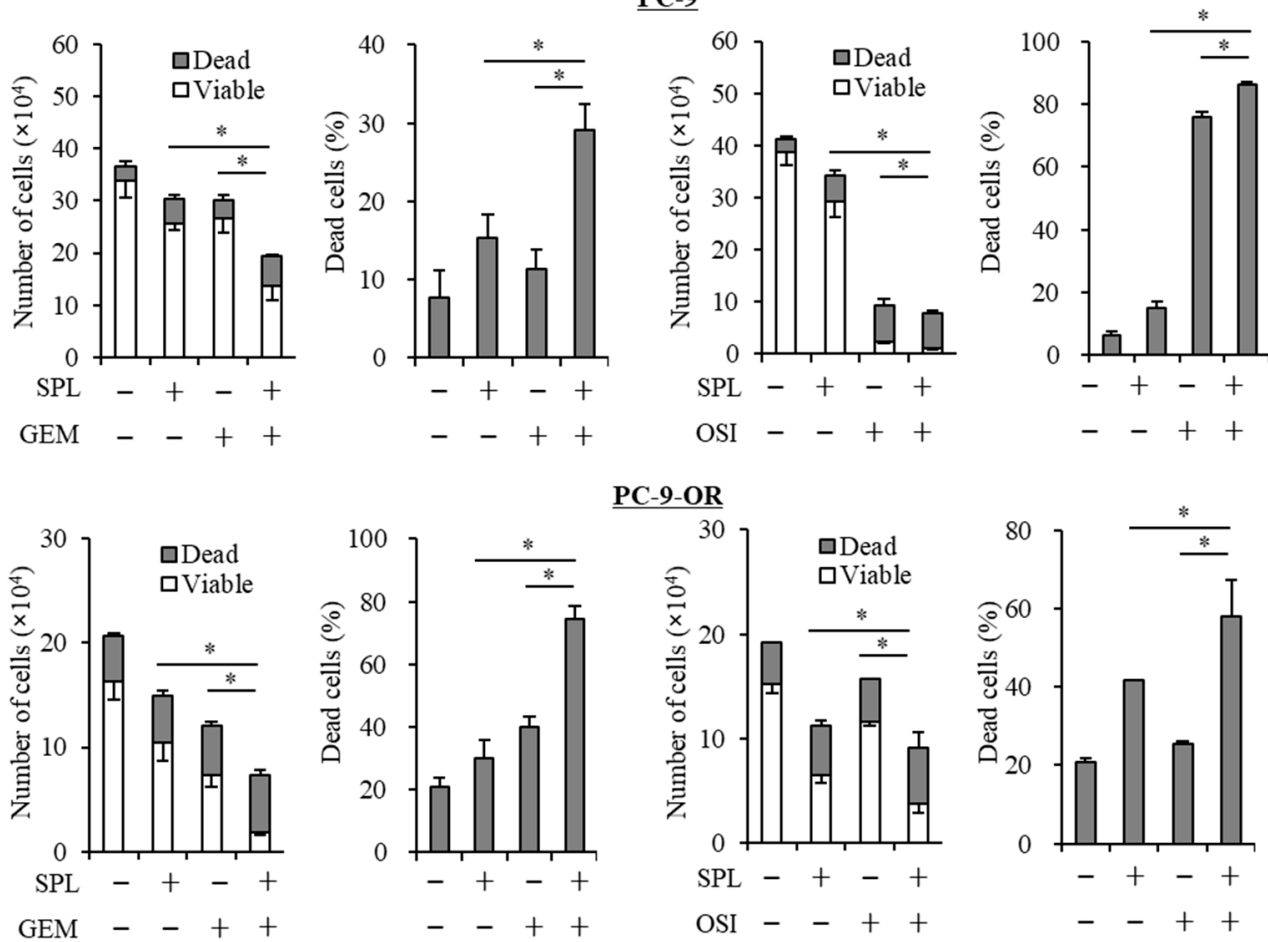

PC-9-OR
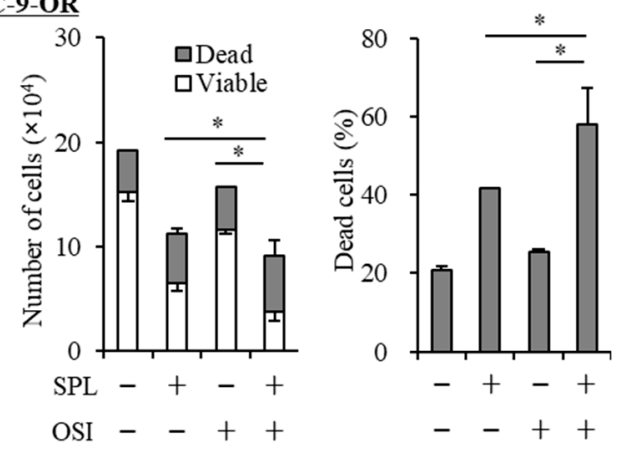

Figure 2. Spironolactone sensitizes cancer cells to anticancer reagents. Cells were treated with the indicated chemotherapeutic reagents (GEM, gemcitabine, $0.1 \mu \mathrm{M}$; OSI, osimertinib, $2 \mu \mathrm{M}$ ) in the absence or presence of $25 \mu \mathrm{M}$ spironolactone (SPL) for three days, and the numbers of viable and dead cells (left panels) as well as the percentage of dead cells (right panels) were then assessed. Values represent the means \pm SD of triplicate samples of a representative experiment repeated with similar results. ${ }^{*} p<0.05$.

\subsection{Spironolactone Reduces Resistance to Gemcitabine and Osimertinib in CSCs.}

To examine whether spironolactone decreases resistance to anticancer reagents in CSCs (A549 CSLC and PANC-1 CSLC cells), which are highly resistant to cytotoxic reagents [42], these cells were co-treated with spironolactone and gemcitabine or osimertinib, and were then subjected to the viability assay. The results obtained showed that spironolactone decreased resistance to these anticancer reagents in CSCs (Figure 3). 

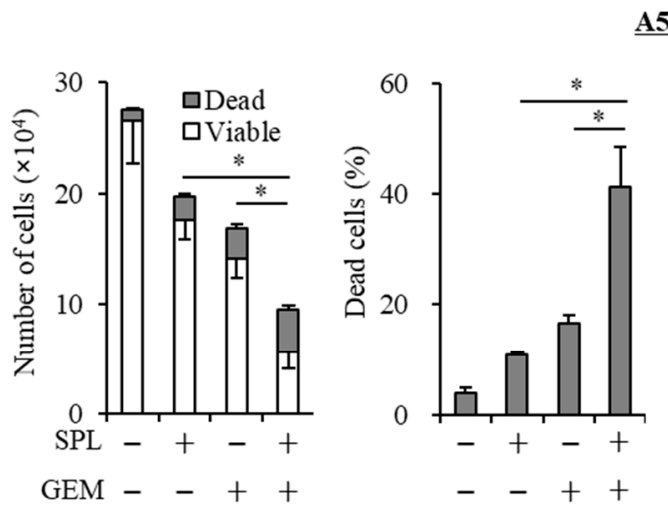

A549 CSLC
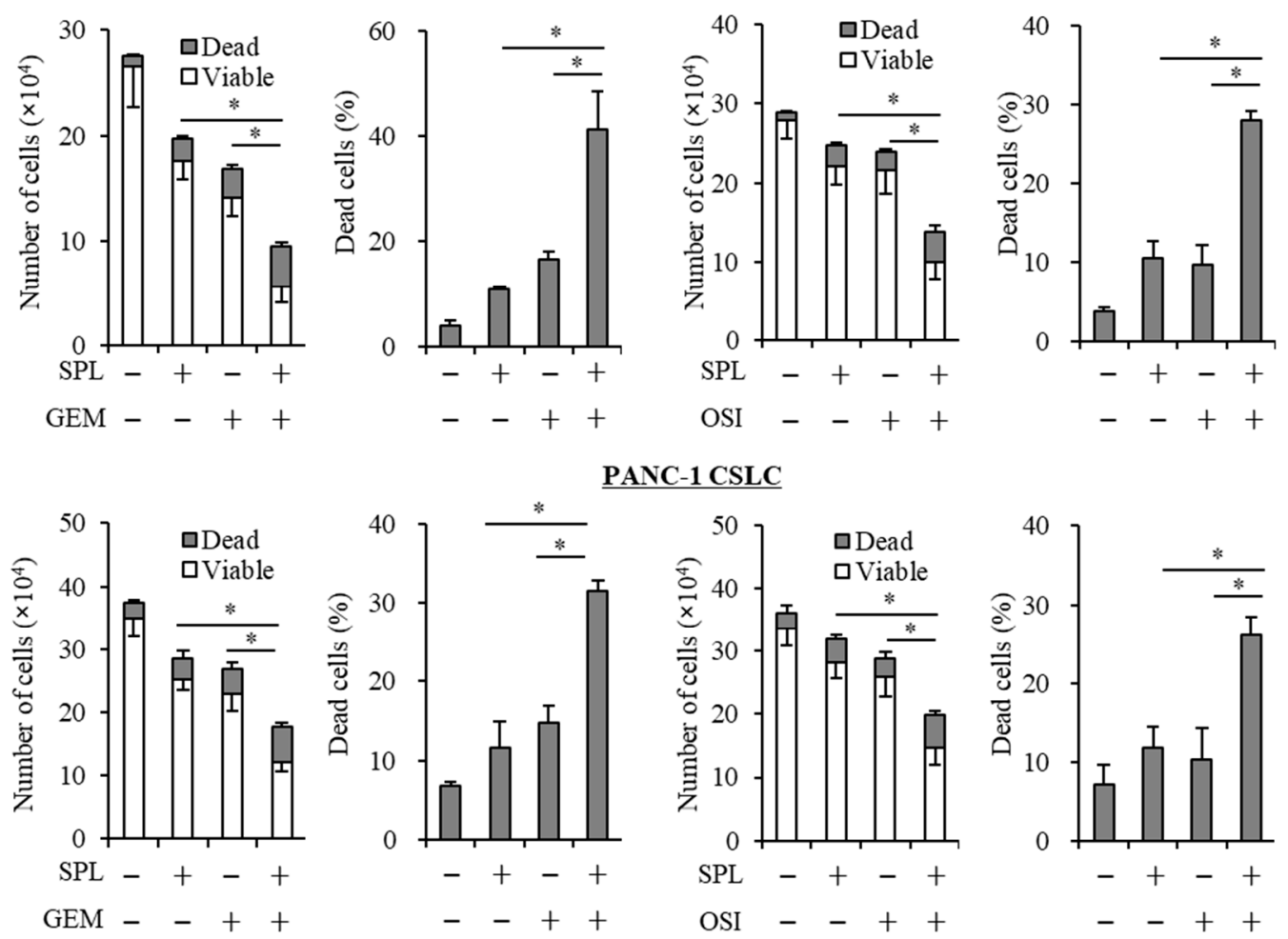

PANC-1 CSLC
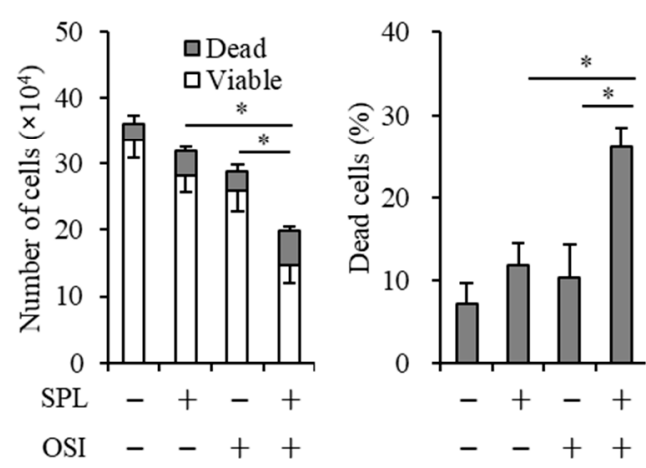

Figure 3. Spironolactone sensitizes cancer stem cells to chemotherapeutic reagents. Cancer stem cells were treated with the indicated chemotherapeutic reagents (GEM, gemcitabine, $0.25 \mu \mathrm{M}$; OSI, osimertinib, $2 \mu \mathrm{M}$ ) in the absence or presence of $25 \mu \mathrm{M}$ spironolactone (SPL) for three days, and the numbers of viable and dead cells (left panels) as well as the percentage of dead cells (right panels) were then assessed. Values represent the means \pm SD of triplicate samples of a representative experiment repeated with similar results. ${ }^{*} p<0.05$.

\subsection{Reductions in Survivin Expression Are Involved in the Potency of Spironolactone to Decrease Resistance to Gemcitabine and Osimertinib}

We investigated the mechanisms by which spironolactone sensitizes cancer cells to gemcitabine and osimertinib. We previously reported that survivin, an anti-apoptotic protein, is involved in osimertinib resistance in glioma stem cells (GSCs), the CSCs of glioblastoma [43], and in NSCLC cells [44], and also that aripiprazole and brexpiprazole, antipsychotic drugs, reduce the expression of survivin and chemosensitize NSCLC and pancreatic cancer cells to gemcitabine [45,46]. Thus, cells treated with spironolactone were subjected to an immunoblot analysis of survivin, and the results obtained showed that survivin expression was decreased by the spironolactone treatment (Figure $4 a, b$ ). Survivin expression levels were markedly lower in IMR-90 cells than in A549 cells, and spironolactone only slightly reduced survivin expression levels (Figure S2). Low survivin levels may explain the weak responsiveness of IMR-90 cells to spironolactone. Furthermore, to elucidate the mechanisms underlying spironolactone-induced reductions in survivin levels, we examined changes in mRNA levels by spironolactone and alterations in protein levels by a treatment with MG132, a proteasome inhibitor. Spironolactone slightly decreased the mRNA levels of survivin (Figure S3), and the treatment with MG132 partially restored the expression of survivin (Figure S4). These results suggest that alterations in mRNA expression levels and proteasome degradation are at least partly involved in the regulation of survivin levels by spironolactone. To examine the involvement of survivin expression in resistance to gemcitabine and to confirm its involvement in osimertinib resistance, we treated A549 cells with YM155, a suppressor of survivin, or siRNA against survivin (siSurvivin) in combination with gemcitabine or osimertinib, and cells were then subjected to immunoblotting and cell viability 
assays (Figure 4c,d). The reduction of survivin by treatment with YM155 and siSurvivin sensitized the cells to gemcitabine and osimertinib, indicating that inhibition of survivin expression is sufficient to chemosensitize A549 NSCLC cells to gemcitabine and osimertinib. Together, these results suggest that reduction of survivin expression by spironolactone sensitizes these cells to gemcitabine and osimertinib most likely through suppression of survivin.

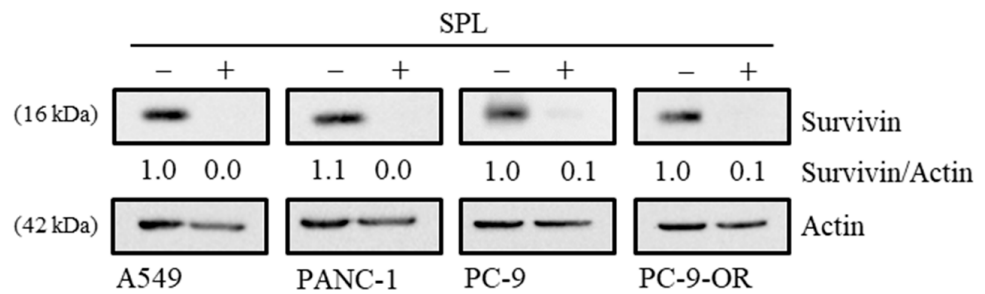

(a)

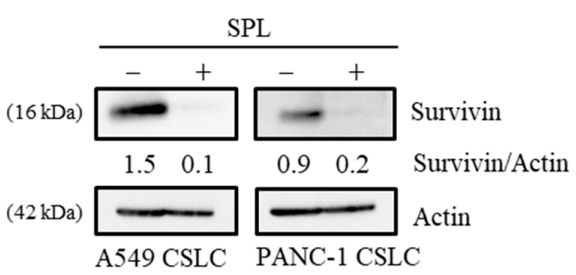

(b)
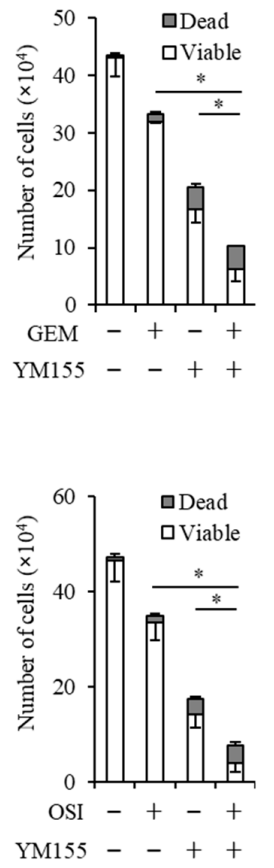
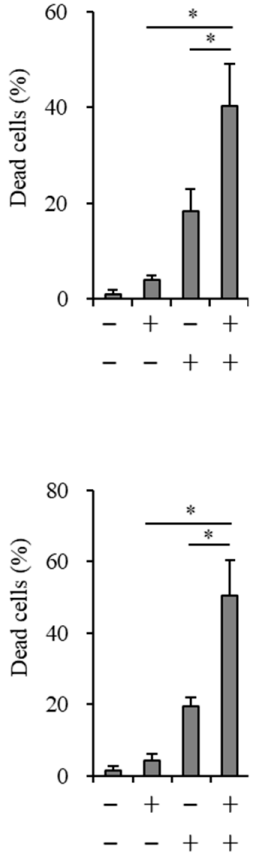

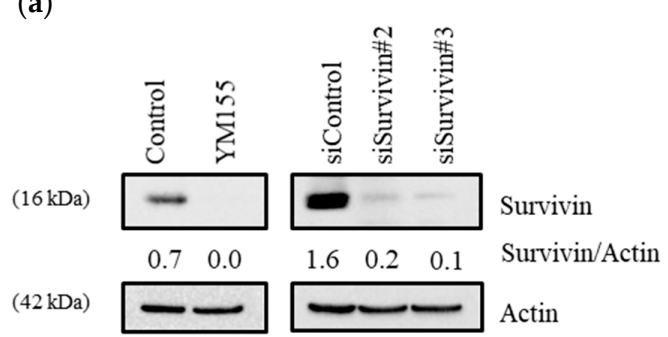

(c)
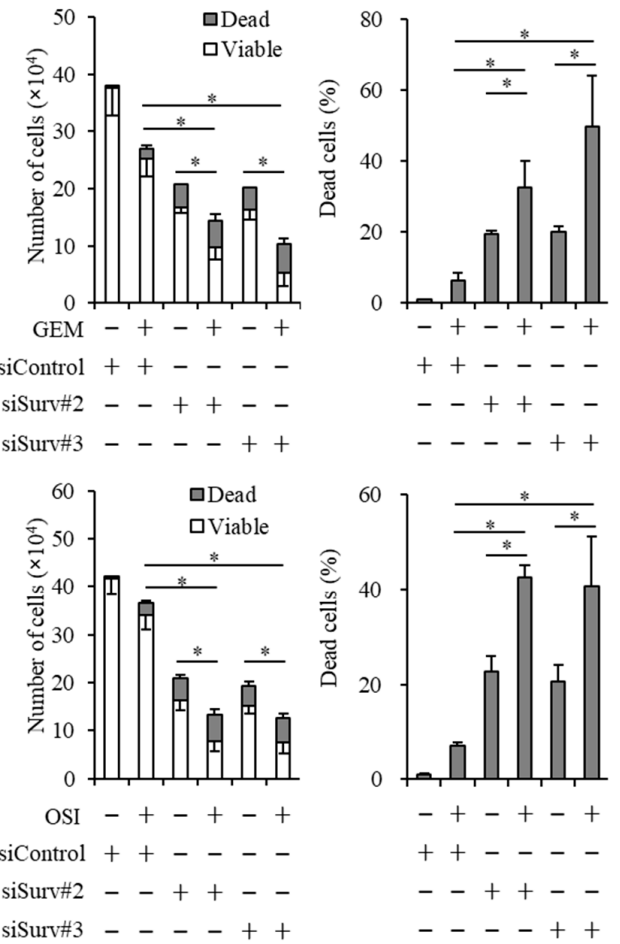

(d)

Figure 4. Spironolactone decreases survivin expression and survivin reductions imitate the chemosensitizing effects of spironolactone. Cells treated with or without $25 \mu \mathrm{M}$ spironolactone (SPL) for three days were subjected to an immunoblot analysis for survivin expression (a,b). YM155, a pharmacological survivin inhibitor, at the concentration of $10 \mathrm{nM}$ and the knockdown of survivin reduced survivin expression in cancer cells (A549) (c). The pharmacological or genetic inhibition of survivin sensitized cancer cells (A549) to chemotherapeutic reagents (GEM, gemcitabine, $0.1 \mu \mathrm{M}$; OSI, osimertinib, $2 \mu \mathrm{M})(\mathbf{d}) .{ }^{*} p<0.05$. 


\subsection{Spironolactone Exerts Anticancer, Chemosensitizing, and EGFR-TKI Sensitizing Effects with Survivin Reductions in Glioma Stem Cells}

Since we previously reported that some treatment strategies for GSCs are mediated by survivin reductions $[43,46]$, we examined whether spironolactone is a potential treatment candidate for GSCs. The results obtained showed that in GS-Y01, a patient-derived GSC line, spironolactone reduced cell viability and increased cell death (Figure 5a) and also reduced the expression of survivin (Figure 5b). Similar to previous findings showing that survivin is involved in the resistance of GSCs to osimertinib [43], the spironolactone treatment sensitized GSCs to osimertinib (Figure 5c).

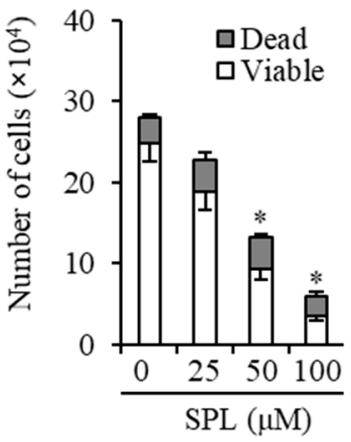

(a)

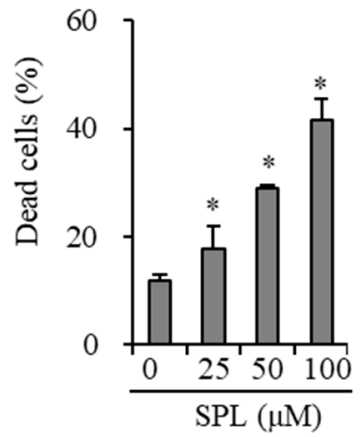

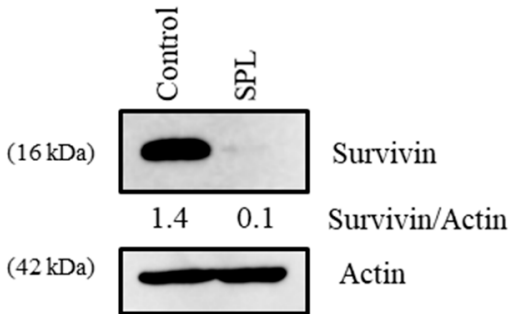

(b)
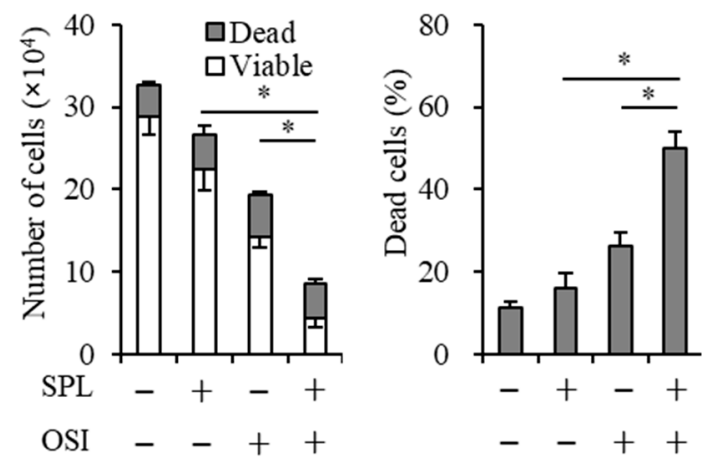

(c)

Figure 5. Spironolactone induces similar effects in GS-Y01, a glioma stem cell line, to those in cancer stem cells (CSCs) of Non-small cell lung cancer (NSCLC) and pancreatic cancer. GS-Y01 cells were treated without (as control) or with the indicated concentrations of spironolactone (SPL) for three days, and the numbers of viable and dead cells (left panel) as well as the percentage of dead cells (right panel) were then assessed (a). Cells treated with or without spironolactone (SPL) for three days were subjected to an immunoblot analysis for survivin expression (b). Glioma stem cells were treated with the indicated chemotherapeutic reagents (OSI, osimertinib) in the absence or presence of spironolactone (SPL) for three days, and the numbers of viable and dead cells (left panel) as well as the percentage of dead cells (right panel) were then assessed (c). Values in the graphs represent the means \pm SD of triplicate samples of a representative experiment repeated with similar results. ${ }^{*} p<0.05$.

\subsection{Spironolactone Augments Anti-Tumor Effects of Osimertinib In Vivo}

The results obtained thus far implied that spironolactone effectively overcomes the resistance of several types of cancer cells to osimertinib in vitro. To evaluate the therapeutic relevance of these results in vivo, we examined the efficacy of the systemic administration of spironolactone and osimertinib alone or in combination against subcutaneous xenografts of lung cancer cells. Since a pilot toxicity study showed that mice tolerated the combination of osimertinib $5 \mathrm{mg} / \mathrm{kg}$ (orally) and spironolactone $25 \mathrm{mg} / \mathrm{kg}$ (intraperitoneally) given 5 times a week, we used this treatment protocol and treated tumors formed by the subcutaneous implantation of A549 cells (EGFR-wt, intrinsically resistant to osimertinib) 
into nude mice. While neither osimertinib nor spironolactone given alone exerted appreciable effects over the control treatment, their combination inhibited the growth of tumors significantly more than the control treatment (Figure 6a). Furthermore, this combination did not appear to exert adverse effects, as assessed by body weight (Figure $6 \mathrm{~b}$ ). These results suggest that spironolactone successfully sensitized otherwise resistant lung cancer cells to osimertinib in vivo.

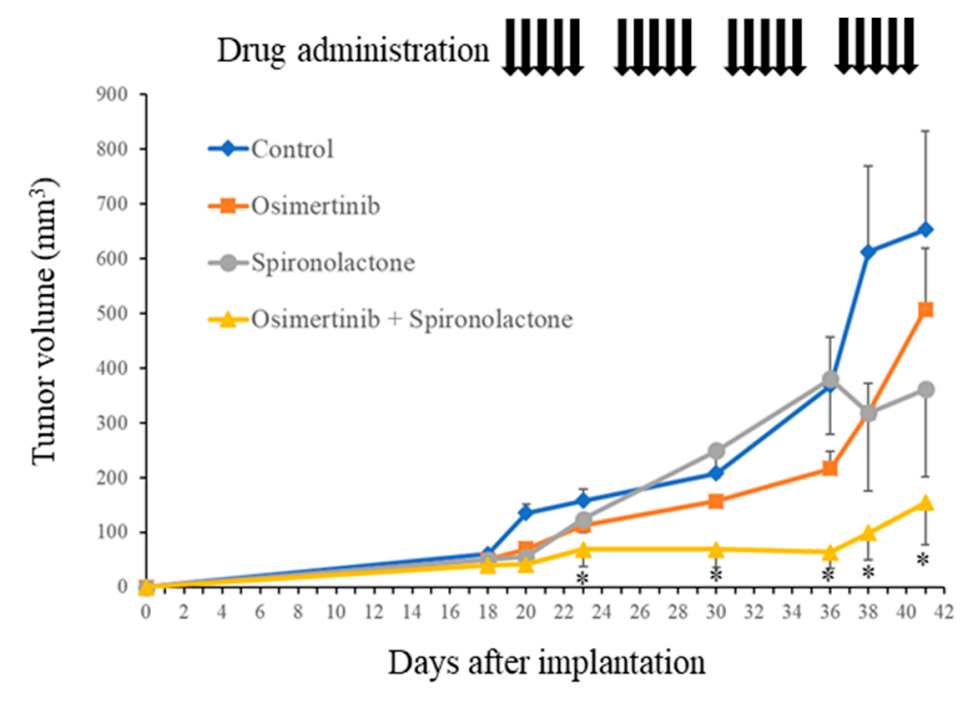

(a)

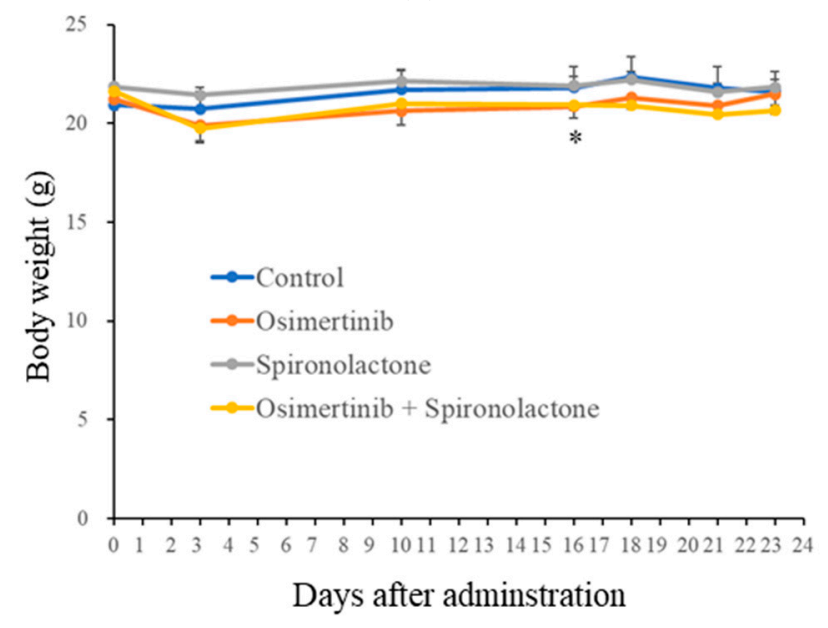

(b)

Figure 6. Spironolactone sensitizes cancer cells to osimertinib in vivo. Mice (five for each group) were subcutaneously implanted with A549 cells. After the confirmation of tumor formation, mice were treated with or without osimertinib and/or spironolactone as detailed in the Materials and Methods. Tumor volume (a) and mouse body weight (b) were measured, and the results obtained are presented in the graphs as the means $\pm \mathrm{SD}$ of each group. ${ }^{*} p<0.05$, compared with control group in (a) and comparison between spironolactone treatment group and combination group in $(\mathbf{b})$.

\section{Discussion}

Since cancer cells are resistant to many types of anticancer reagents by various mechanisms, extensive research has been performed to overcome chemoresistance. We examined the anticancer effects of spironolactone, a classic potassium-sparing diuretic that is used for cancer patients with ascites, hypertension induced by anti-VEGF therapy, and brain edema related to brain tumors, from the perspective of drug repositioning or repurposing. We revealed that spironolactone suppressed the 
expression of survivin, an anti-apoptotic protein, at a concentration that was harmless to non-cancer cells and also chemosensitized cancer cells and CSCs to anticancer reagents, such as gemcitabine and osimertinib. Therefore, spironolactone is a good candidate drug for the treatment of cancer.

There are several sources of chemoresistance to cancer including alterations to drug transporters, the suppression of apoptosis, mitochondrial alterations, the promotion of DNA damage repair, autophagy, epithelial-mesenchymal transition, and CSCs [2-5]. Previous studies reported that spironolactone inhibits DNA repair and chemosensitizes cancer cells to DNA-damaging reagents, such as cisplatin [39-41]. In the present study, we revealed that spironolactone chemosensitized cancer cells to gemcitabine and osimertinib. Gemcitabine is a nucleoside analog that is incorporated into DNA and prevents elongation of the DNA chain, leading to cell death $[47,48]$. Osimertinib is an inhibitor of epidermal growth factor receptor tyrosine kinase (EGFR-TKI) that suppresses EGFR signaling [24]. Since the main mechanism of action of gemcitabine and osimertinib is not damage to DNA, the chemosensitizing effects of spironolactone to gemcitabine and osimertinib may be mediated by mechanisms other than the suppression of DNA repair. We and others reported that drugs that suppress survivin chemosensitize cancer cells to EGFR-TKIs [43,48-51] and gemcitabine [52]. Survivin is a member of the inhibitor of apoptotic protein (IAPs) family, which suppresses apoptosis by modulating the execution of extrinsic and intrinsic apoptotic signals. We showed that spironolactone reduced the expression of survivin in cancer cells and sensitized these cells to these anticancer reagents. Similarly, the suppression of survivin by YM155, a transcriptional suppressor of survivin, or siRNA against survivin chemosensitized these cells to anticancer reagents. These results suggest that survivin is involved in chemoresistance to gemcitabine and osimertinib in cancer cells and the CSCs of NSCLC and pancreatic cancer, and also that spironolactone chemosensitizes NSCLC, pancreatic cancer, and glioblastoma cells to gemcitabine and osimertinib most likely through the suppression of survivin.

Survivin expression is regulated by several mechanisms, including mRNA expression and proteasome degradation. YM155, a clinically examined survivin suppressor, reduces survivin expression levels by suppressing the transcription of survivin. In the present study, we revealed that spironolactone reduced survivin mRNA levels to a lesser extent, and MG132, a proteasome inhibitor, partially restored spironolactone-induced decreases in survivin. These results suggest that spironolactone reduces survivin by mRNA reductions and increased degradation by proteasomes. Spironolactone induces the degradation of XPB, a major component of transcription factor II, and impairs transcription activity [40]. Furthermore, the ubiquitin-proteasome pathway regulates the stability of survivin [43,53-55]. The ubiquitination of survivin is controlled by the E3 ligases FBXL7 [53] and cullin 9 [54], and by the deubiquitinase USP9X [55]. Further studies are needed to elucidate the involvement of XPB and these ubiquitination-related enzymes in spironolactone-induced reductions in survivin.

Spironolactone is a well-known and widely-used potassium-sparing diuretic reagent that mainly antagonizes mineralocorticoid (or aldosterone) receptors. However, we noted that a representative mineralocorticoid receptor agonist, aldosterone, did not rescue the effects of spironolactone on survivin reductions (Figure S5). Moreover, more specific selective mineralocorticoid receptor antagonists, second- and third-generation potassium-sparing diuretic reagents, such as eplerenone [56] and esaxerenone [57], have more limited effects on survivin expression than the first-generation, less selective potassium-sparing diuretic, spironolactone (Figure S6). Similar to the present results, eplerenone was previously shown to not inhibit nucleotide excision repair (NER) or the proliferation of cancer cells $[39,40]$. Although the main target of spironolactone is mineralocorticoid receptors, spironolactone also binds to receptors related to mineralocorticoid receptors and exerts antiandrogen and weak progesterone properties as well as some indirect estrogenic and glucocorticoid effects [57]. These results imply the involvement of receptors other than mineralocorticoid receptors, such as glucocorticoid receptors, in chemosensitizing effects.

There are obstacles to applying the present results to clinical settings. The concentration used in our in vitro studies $(25 \mu \mathrm{M})$ may be higher than the expected tissue concentration observed in humans. In other studies, similar concentrations of spironolactone (10 or $40 \mu \mathrm{M})$ were required to exert 
anti-cancer effects in vitro [39-41]. Since spironolactone is converted into several active metabolites (canrenone, $7 \alpha$-thiomethyl-spironolactone, and $6 \beta$-hydroxy-7 $\alpha$-spironolactone) mainly in the liver in vivo [58] and shows complex tissue distribution, higher concentrations of spironolactone may be needed to exert anti-cancer effects in vitro. Further studies are needed to address this issue, as indicated previously by Gold et al. [39]. By taking dose conversions from mice to humans [59] into consideration, the dosage used in the in vivo study ( $25 \mathrm{mg} / \mathrm{kg}$ body weight) corresponds to $2.03 \mathrm{mg} / \mathrm{kg}$ for humans, which is an acceptable dosage used in clinical settings. The acceptable dosage of spironolactone showed combinational effects with osimertinib on tumor growth, and these results strongly suggest the clinical application of spironolactone for patients with cancer.

In conclusion, we herein reported that spironolactone exerted anticancer and chemosensitizing effects on various types of cancers most likely through survivin reductions. Importantly, the suppression of survivin is a novel mechanism for the chemosensitizing effects of spironolactone in combination with non-DNA-damaging chemotherapeutic reagents, such as gemcitabine and osimertinib. Therefore, spironolactone has potential as a promising anticancer drug for NSCLC, pancreatic cancer, and glioblastoma in combination with non-DNA-damaging anti-cancer drugs as well as DNA-damaging drugs with a known excellent safety profile.

\section{Materials and Methods}

\subsection{Antibodies and Reagents}

An anti-survivin (\#2808) antibody was purchased from Cell Signaling Technology, Inc. (Beverly, MA, USA). An anti- $\beta$-actin (A1978) antibody was from Sigma (St. Louis, MO, USA). Gemcitabine was also from Sigma, and was dissolved in dimethyl sulfoxide (DMSO) to prepare a $1 \mathrm{mM}$ stock solution. Spironolactone and eplerenone were from Tokyo Kasei Kogyo (Tokyo, Japan) and dissolved in DMSO to prepare a $100 \mathrm{mM}$ stock solution. Osimertinib and YM155 were purchased from Chemscene LLC. (Monmouth Junction, NJ, USA) and dissolved in DMSO to $10 \mathrm{mM}$ and $20 \mu \mathrm{M}$, respectively, as stock solutions. Aldosterone was from Toronto Research (North York, Canada) and dissolved in DMSO to a $100 \mathrm{mM}$ stock solution. Esaxerenone was from Medchem (Monmouth Junction, NJ, USA) and dissolved in DMSO to a $50 \mathrm{mM}$ stock solution. MG132 was from Wako Pure Chemical Industries (Osaka, Japan) and dissolved in DMSO to a $10 \mathrm{mM}$ stock solution.

\subsection{Cell Culture}

The human non-small cell lung cancer (NSCLC) cell lines A549 and PC-9 were obtained from the Riken BioResource Center (Tsukuba, Japan). The human pancreatic cell line PANC-1 was from the Cell Resource Center for Biomedical Research, Institute of Development, Aging and Cancer, Tohoku University (Sendai, Japan). A549 and PANC-1 cell lines were both cultured in DMEM/F12 medium and PC-9 was cultured in RPMI1640 medium instead of DMEM/F12 medium, and these cell line media were supplemented with $10 \%$ fetal bovine serum (FBS), 100 units $/ \mathrm{mL}$ of penicillin, and $100 \mu \mathrm{g} / \mathrm{mL}$ of streptomycin. An osimertinib-resistant subline of PC-9 (PC-9-OR) was established by culturing in increasing concentrations of osimertinib $(0.1-1.5 \mu \mathrm{M})$ over a two-month period. PC-9-OR cells were maintained in the presence of $1.5 \mu \mathrm{M}$ osimertinib. The establishment of A549 CSLC and PANC-1 CSLC was previously reported $[60,61]$. The authenticity of A549 CSLC and PANC-1 CSLC was verified by the genotyping of short tandem repeat (STR) loci (Bio-Synthesis, Inc., Lewisville, TX, USA) and comparisons with the ATCC STR database for Human Cell Lines. GS-Y01 is a CSC line derived from a glioma patient [62]. These CSCs were cultured as previously described [60,63,64]. Briefly, these cells were cultured on collagen I-coated dishes (IWAKI, Tokyo, Japan) in the stem cell culture medium (DMEM/F12 medium with 1\% B27 supplement (Gibco-BRL, Carlsbad, CA, USA), $20 \mathrm{ng} / \mathrm{mL}$ of EGF and FGF2 (Peprotech, Inc., Rocky Hill, NJ, USA), D-(+)-glucose (final concentration, $26.2 \mathrm{mM}$ ), L-glutamine (final concentration, $4.5 \mathrm{mM}$ ), 100 units $/ \mathrm{mL}$ of penicillin, and $100 \mu \mathrm{g} / \mathrm{mL}$ of streptomycin). Stem cell culture medium was changed every three days, and EGF and FGF2 were supplemented into the culture 
medium every day. IMR90, normal human fetal lung fibroblasts, were purchased from the American Type Culture Collection, and cultured in DMEM/F12 supplemented with 10\% FBS, 100 units/mL penicillin, and $100 \mu \mathrm{g} / \mathrm{mL}$ streptomycin. All experiments with IMR90 were performed within a low passage number (less than eight).

\subsection{Cell Viability Assays}

Viable and dead cells were identified by their ability and inability to exclude vital dyes, respectively $[52,64]$. Briefly, cells were stained with $0.2 \%$ trypan blue, and the numbers of viable and dead cells were counted using a hemocytometer. Dead cells (\%) were defined as $100 \times$ 'the number of dead cells'/('the number of viable cells' + 'the number of dead cells'). The following formula was used to obtain $\mathrm{IC}_{50}$ values, as previously reported [65]: $\mathrm{IC}_{50}=10^{[\log (\mathrm{A} / \mathrm{B}) \times(50-\mathrm{C})] /[(\mathrm{D}-\mathrm{C})+\log (\mathrm{B})]}$, where $\mathrm{A}$ and $\mathrm{B}$ are the corresponding concentrations of the test drug directly above and below $50 \%$ inhibition, respectively, and C and D are the percentages of inhibition directly below and above $50 \%$ inhibition, respectively.

\subsection{Gene Silencing with siRNA}

Two siRNAs against human survivin (BIRC5 \#2; HSS 179404, \#3; HSS 179405) and Medium GC Duplex \#2 of Stealth RNAi ${ }^{\mathrm{TM}}$ siRNA Negative Control Duplexes (non-targeting control) were obtained from Thermo Fisher Scientific (Waltham, MA, USA). Cells were transiently transfected with RNAs using Lipofectamine RNAiMAX ${ }^{\mathrm{TM}}$ (Thermo Fisher Scientific) according to the manufacturer's instructions.

\subsection{Mouse Study}

A mouse xenograft study was performed as previously described [52]. Regarding subcutaneous implantation, A549 cells $\left(1 \times 10^{6}\right.$ cells) suspended in $200 \mu \mathrm{L}$ of PBS were implanted subcutaneously into the flank region of 7-week-old male BALB/cAJcl-nu/nu mice (CLEA Japan, Inc., Tokyo, Japan) after being anesthetized with an intraperitoneal injection of medetomidine, midazolam, and butorphanol $(0.3,4$, and $5 \mathrm{mg}$ per $\mathrm{kg}$ body weight, respectively). After implantation, the general health status and presence of subcutaneous tumors were measured. Tumor volumes were assessed by measuring tumor diameters using a caliper and calculated as the larger diameter $\times$ the smaller diameter $\times$ height. Regarding the systemic administration of drugs, stock solutions of spironolactone $(10 \mathrm{mg} / \mathrm{mL})$ and osimertinib $(2 \mathrm{mg} / \mathrm{mL})$ were diluted in DMSO to prepare $100 \mu \mathrm{L}$ solutions for each injection. Spironolactone was intraperitoneally administered to mice at $25 \mathrm{mg} / \mathrm{kg}$ body weight 5 times a week and osimertinib was orally administered at $5 \mathrm{mg} / \mathrm{kg} 5$ times a week. The drug treatment was started after the confirmation of subcutaneous tumor formation, and tumor-bearing mice were randomized into 4 groups before the initiation of drug treatment. All animal experimental protocols were approved by the Animal Research Committee of Yamagata University (protocol code: 30027).

\subsection{Immunoblot Analysis}

Cells were washed with PBS and lysed in RIPA buffer (10 mM Tris-HCl [pH 7.4], 0.1\% SDS, 0.1\% sodium deoxycholate, $1 \% \mathrm{NP}-40,150 \mathrm{mM} \mathrm{NaCl}, 1 \mathrm{mM}$ EDTA, $1.5 \mathrm{mM} \mathrm{Na}_{3} \mathrm{VO}_{4}, 10 \mathrm{mM} \mathrm{NaF}, 10 \mathrm{mM}$ sodium pyrophosphate, $10 \mathrm{mM}$ sodium $\beta$-glycerophosphate, and $1 \%$ protease inhibitor cocktail set III Sigma). After centrifugation at $14,000 \times g$ at $4{ }^{\circ} \mathrm{C}$ for $10 \mathrm{~min}$, supernatants were harvested as cell lysate samples, and the protein concentrations of the cell lysates were measured using a BCA protein assay kit (Pierce Biotechnology, Inc., Rockford, IL, USA). Cell lysates containing equal amounts of protein were separated by SDS-PAGE and transferred to polyvinylidene difluoride membranes. Membranes were probed with primary antibodies and then with an appropriate HRP-conjugated secondary antibody according to the manufacturer's protocol. Immunoreactive bands were visualized using Immobilon Western Chemiluminescent HRP Substrate (Merck Millipore, Darmstadt, Germany). The relative density of immunoreactive bands was analyzed by densitometry using ImageJ 1.52a software (National Institutes of Health, Bethesda, MD, USA). 


\subsection{RNA Extraction and Reverse Transcription-PCR}

Total RNA was isolated using Trizol (Thermo Fisher Scientific) according to the manufacturer's instructions. RNA was reverse-transcribed into cDNA using the PrimeScript 1st strand cDNA Synthesis Kit (Takara Bio, Kusatsu, Japan). Synthesized cDNA samples were amplified by PCR using Quick Taq HS DyeMix (Toyobo, Osaka, Japan). The primer sequences used were as follows: actin (5'-CCCATGCCATCCTGCGTCTG-3' [forward] and 5' -CGTCATACTCCTGCTTGCTG -3' [reverse]), and survivin (5'-CCTTTCTCAAGGACCACCGCATCT-3' [forward] and 5'-CGCACTTTCTCCGCA GTTTCCT-3' [reverse]).

\subsection{Statistical Analysis}

Results are expressed as means and standard deviations (SD) and differences were compared using the two-tailed Student's $t$-test. $p$-values $<0.05$ were considered to be significant and were indicated with asterisks.

\section{Conclusions}

The anticancer and chemosensitizing effects of spironolactone on various types of cancer cells appear to be attributed to survivin reductions, and the suppression of survivin is a novel mechanism for the chemosensitizing effects of spironolactone in combination with non-DNA-damaging chemotherapeutic drugs, such as gemcitabine and osimertinib.

Supplementary Materials: The following are available online at http://www.mdpi.com/2072-6694/11/10/1550/s1, Figure S1: Effects of spironolactone on the viability of A549 cells treated with gemcitabine and osimertinib, Figure S2: IMR90 cells express markedly lower levels of survivin than cancer cells, Figure S3: Spironolactone decreases survivin mRNA levels to a lesser extent. A549 cells treated with or without $25 \mu \mathrm{M}$ spironolactone for three days were subjected to a reverse transcription-PCR analysis of survivin, Figure S4: MG132 partially restores spironolactone-induced reductions in survivin, Figure S5: Effects of aldosterone on survivin reductions by spironolactone, Figure S6: Effects of next-generation potassium-sparing diuretic reagents, eplerenone and esaxerenone, on the expression of survivin, Figure S7: Original electrophoresis gels and immunoblotting membranes.

Author Contributions: Conceptualization, T.S., S.S. (Shuhei Suzuki), M.O., C.K. and M.Y.; Data curation, T.S. and S.S. (Shuhei Suzuki); Formal analysis, T.S., S.S. (Shuhei Suzuki) and M.Y.; Funding acquisition, T.S., S.S. (Shuhei Suzuki), M.O., C.K. and M.Y.; Investigation, T.S. and S.S. (Shuhei Suzuki); Methodology, T.S. and S.S. (Shuhei Suzuki); Project administration, C.K.; Resources, T.S., S.S. (Shuhei Suzuki), S.S. (Shizuka Seino), M.O., C.K. and M.Y.; Software, S.S. (Shuhei Suzuki) and M.Y.; Supervision, M.O., C.K. and M.Y.; Validation, T.S., S.S. (Shuhei Suzuki) and M.Y.; Visualization, A.S.; Writing-original draft, T.S., S.S. (Shuhei Suzuki) and M.Y.; Writing-review \& editing, K.T., A.S., S.S. (Shizuka Seino), M.O. and T.Y.

Funding: This study was funded by Grants-in-Aid for Scientific Research, for Challenging Exploratory Research, and for Young Scientists from the Ministry of Education, Culture, Sports, Science, and Technology of Japan.

Acknowledgments: This work was supported by Grants-in-Aid for Scientific Research, for Challenging Exploratory Research, and for Young Scientists from the Ministry of Education, Culture, Sports, Science, and Technology of Japan.

Conflicts of Interest: The authors declare no conflicts of interest.

\section{References}

1. Siegel, R.L.; Miller, K.D.; Jemal, A. Cancer statistics, 2019. CA Cancer J. Clin. 2019, 69, 7-34. [CrossRef] [PubMed]

2. Fojo, T.; Bates, S. Strategies for reversing drug resistance. Oncogene 2003, 22, 7512-7523. [CrossRef] [PubMed]

3. Kachalaki, S.; Ebrahimi, M.; Khosroshahi, L.M.; Mohammadinejad, S.; Baradaran, B. Cancer Chemoresistance; Biochemical and Molecular Aspects: A brief overview. Eur. J. Pharm. Sci. 2016, 89, 20-30. [CrossRef] [PubMed]

4. Longley, D.B.; Johnston, P.G. Molecular mechanisms of drug resistance. J. Pathol. 2005, 205, $275-292$. [CrossRef] 
5. Zheng, H.C. The molecular mechanisms of chemoresistance in cancers. Oncotarget 2017, 8, 59950-59964. [CrossRef]

6. Housman, G.; Byler, S.; Heerboth, S.; Lapinska, K.; Longacre, M.; Snyder, N.; Sarkar, S. Drug resistance in cancer: An overview. Cancers 2014, 6, 1769-1792. [CrossRef]

7. Howlader, N.; Noone, A.M.; Krapcho, M.; Miller, D.; Brest, A.; Yu, M.; Ruhl, J.; Tatalovich, Z.; Mariotto, A.; Lewis, D.R.; et al. (Eds.) SEER Cancer Statistics Review, 1975-2016; National Cancer Institute: Bethesda, MD, USA. Available online: https://seer.cancer.gov/csr/1975_2016/(accessed on 20 April 2019).

8. Van Moorsel, C.J.; Peters, G.J.; Pinedo, H.M. Gemcitabine: Future Prospects of Single-Agent and Combination Studies. Oncologist 1997, 2, 127-134.

9. Morabito, A.; Gebbia, V.; Di Maio, M.; Cinieri, S.; Vigano, M.G.; Bianco, R.; Barbera, S.; Cavanna, L.; De Marinis, F.; Montesarchio, V.; et al. Randomized phase III trial of gemcitabine and cisplatin vs. gemcitabine alone in patients with advanced non-small cell lung cancer and a performance status of 2: The CAPPA-2 study. Lung Cancer 2013, 81, 77-83. [CrossRef]

10. Kim, M.P.; Gallick, G.E. Gemcitabine resistance in pancreatic cancer: Picking the key players. Clin. Cancer Res. 2008, 14, 1284-1285. [CrossRef]

11. Dyawanapelly, S.; Kumar, A.; Chourasia, M.K. Lessons Learned from Gemcitabine: Impact of Therapeutic Carrier Systems and Gemcitabine's Drug Conjugates on Cancer Therapy. Crit. Rev. Ther. Drug Carr. Syst. 2017, 34, 63-96. [CrossRef]

12. Yarden, Y.; Pines, G. The ERBB network: At last, cancer therapy meets systems biology. Nat. Rev. Cancer 2012, 12, 553-563. [CrossRef]

13. Sigismund, S.; Avanzato, D.; Lanzetti, L. Emerging functions of the EGFR in cancer. Mol. Oncol. 2018, 12, 3-20. [CrossRef]

14. Kobayashi, S.; Boggon, T.J.; Dayaram, T.; Janne, P.A.; Kocher, O.; Meyerson, M.; Johnson, B.E.; Eck, M.J.; Tenen, D.G.; Halmos, B. EGFR mutation and resistance of non-small-cell lung cancer to gefitinib. N. Engl. J. Med. 2005, 352, 786-792. [CrossRef]

15. Moore, M.J.; Goldstein, D.; Hamm, J.; Figer, A.; Hecht, J.R.; Gallinger, S.; Au, H.J.; Murawa, P.; Walde, D.; Wolff, R.A.; et al. Erlotinib plus gemcitabine compared with gemcitabine alone in patients with advanced pancreatic cancer: A phase III trial of the National Cancer Institute of Canada Clinical Trials Group. J. Clin. Oncol. 2007, 25, 1960-1966. [CrossRef]

16. Okusaka, T.; Furuse, J.; Funakoshi, A.; Ioka, T.; Yamao, K.; Ohkawa, S.; Boku, N.; Komatsu, Y.; Nakamori, S.; Iguchi, H.; et al. Phase II study of erlotinib plus gemcitabine in Japanese patients with unresectable pancreatic cancer. Cancer Sci. 2011, 102, 425-431. [CrossRef]

17. Yang, Z.Y.; Yuan, J.Q.; Di, M.Y.; Zheng, D.Y.; Chen, J.Z.; Ding, H.; Wu, X.Y.; Huang, Y.F.; Mao, C.; Tang, J.L. Gemcitabine plus erlotinib for advanced pancreatic cancer: A systematic review with meta-analysis. PLOS ONE 2013, 8, e57528. [CrossRef]

18. Rich, J.N.; Reardon, D.A.; Peery, T.; Dowell, J.M.; Quinn, J.A.; Penne, K.L.; Wikstrand, C.J.; Van Duyn, L.B.; Dancey, J.E.; McLendon, R.E.; et al. Phase II trial of gefitinib in recurrent glioblastoma. J. Clin. Oncol. 2004, 22, 133-142. [CrossRef]

19. Van den Bent, M.J.; Brandes, A.A.; Rampling, R.; Kouwenhoven, M.C.; Kros, J.M.; Carpentier, A.F.; Clement, P.M.; Frenay, M.; Campone, M.; Baurain, J.F.; et al. Randomized phase II trial of erlotinib versus temozolomide or carmustine in recurrent glioblastoma: EORTC brain tumor group study 26034. J. Clin. Oncol. 2009, 27, 1268-1274. [CrossRef]

20. Westphal, M.; Maire, C.L.; Lamszus, K. EGFR as a Target for Glioblastoma Treatment: An Unfulfilled Promise. CNS Drugs 2017, 31, 723-735. [CrossRef]

21. Chakravarti, A.; Wang, M.; Robins, H.I.; Lautenschlaeger, T.; Curran, W.J.; Brachman, D.G.; Schultz, C.J.; Choucair, A.; Dolled-Filhart, M.; Christiansen, J.; et al. RTOG 0211: A phase 1/2 study of radiation therapy with concurrent gefitinib for newly diagnosed glioblastoma patients. Int. J. Radiat. Oncol. Biol. Phys. 2013, 85, 1206-1211. [CrossRef]

22. Janne, P.A.; Yang, J.C.; Kim, D.W.; Planchard, D.; Ohe, Y.; Ramalingam, S.S.; Ahn, M.J.; Kim, S.W.; Su, W.C.; Horn, L.; et al. AZD9291 in EGFR inhibitor-resistant non-small-cell lung cancer. N. Engl. J. Med. 2015, 372, 1689-1699. [CrossRef] 
23. Mok, T.S.; Wu, Y.L.; Ahn, M.J.; Garassino, M.C.; Kim, H.R.; Ramalingam, S.S.; Shepherd, F.A.; He, Y.; Akamatsu, H.; Theelen, W.S.; et al. Osimertinib or Platinum-Pemetrexed in EGFR T790M-Positive Lung Cancer. N. Engl. J. Med. 2017, 376, 629-640. [CrossRef]

24. Soria, J.C.; Ohe, Y.; Vansteenkiste, J.; Reungwetwattana, T.; Chewaskulyong, B.; Lee, K.H.; Dechaphunkul, A.; Imamura, F.; Nogami, N.; Kurata, T.; et al. Osimertinib in Untreated EGFR-Mutated Advanced Non-Small-Cell Lung Cancer. N. Engl. J. Med. 2018, 378, 113-125. [CrossRef]

25. Murtuza, A.; Bulbul, A.; Shen, J.P.; Keshavarzian, P.; Woodward, B.D.; Lopez-Diaz, F.J.; Lippman, S.M.; Husain, H. Novel Third-Generation EGFR Tyrosine Kinase Inhibitors and Strategies to Overcome Therapeutic Resistance in Lung Cancer. Cancer Res. 2019, 79, 689-698. [CrossRef]

26. Ashburn, T.T.; Thor, K.B. Drug repositioning: Identifying and developing new uses for existing drugs. Nat. Rev. Drug Discov. 2004, 3, 673-683. [CrossRef]

27. Langedijk, J.; Mantel-Teeuwisse, A.K.; Slijkerman, D.S.; Schutjens, M.H. Drug repositioning and repurposing: Terminology and definitions in literature. Drug Discov. Today 2015, 20, 1027-1034. [CrossRef]

28. Xue, H.; Li, J.; Xie, H.; Wang, Y. Review of Drug Repositioning Approaches and Resources. Int. J. Biol. Sci. 2018, 14, 1232-1244. [CrossRef]

29. Wu, M.; Yu, Q.; Li, Q. Differences in reproductive toxicology between alopecia drugs: An analysis on adverse events among female and male cases. Oncotarget 2016, 7, 82074-82084. [CrossRef]

30. Schwab, C.; Jagannath, S. The role of thalidomide in multiple myeloma. Clin. Lymphoma Myeloma 2006, 7, 26-29. [CrossRef]

31. Eisen, H.J.; Tuzcu, E.M.; Dorent, R.; Kobashigawa, J.; Mancini, D.; Valantine-von Kaeppler, H.A.; Starling, R.C.; Sorensen, K.; Hummel, M.; Lind, J.M.; et al. Everolimus for the prevention of allograft rejection and vasculopathy in cardiac-transplant recipients. N. Engl. J. Med. 2003, 349, 847-858. [CrossRef]

32. Motzer, R.J.; Escudier, B.; Oudard, S.; Hutson, T.E.; Porta, C.; Bracarda, S.; Grunwald, V.; Thompson, J.A.; Figlin, R.A.; Hollaender, N.; et al. Efficacy of everolimus in advanced renal cell carcinoma: A double-blind, randomised, placebo-controlled phase III trial. Lancet 2008, 372, 449-456. [CrossRef]

33. Baselga, J.; Campone, M.; Piccart, M.; Burris, H.A., 3rd; Rugo, H.S.; Sahmoud, T.; Noguchi, S.; Gnant, M.; Pritchard, K.I.; Lebrun, F.; et al. Everolimus in postmenopausal hormone-receptor-positive advanced breast cancer. N. Engl. J. Med. 2012, 366, 520-529. [CrossRef]

34. Yao, J.C.; Fazio, N.; Singh, S.; Buzzoni, R.; Carnaghi, C.; Wolin, E.; Tomasek, J.; Raderer, M.; Lahner, H.; Voi, M.; et al. Everolimus for the treatment of advanced, non-functional neuroendocrine tumours of the lung or gastrointestinal tract (RADIANT-4): A randomised, placebo-controlled, phase 3 study. Lancet 2016, 387, 968-977. [CrossRef]

35. Greenway, B.; Johnson, P.J.; Williams, R. Control of malignant ascites with spironolactone. Br. J. Surg. 1982, 69, 441-442. [CrossRef]

36. Chen, J.; Lu, Y.; Zheng, Y. Incidence and risk of hypertension with bevacizumab in non-small-cell lung cancer patients: A meta-analysis of randomized controlled trials. Drug Des. Dev. Ther. 2015, 9, 4751-4760. [CrossRef]

37. Wang, Z.; Xu, J.; Nie, W.; Huang, G.; Tang, J.; Guan, X. Risk of hypertension with regorafenib in cancer patients: A systematic review and meta-analysis. Eur. J. Clin. Pharmacol. 2014, 70, 225-231. [CrossRef]

38. Esquenazi, Y.; Lo, V.P.; Lee, K. Critical Care Management of Cerebral Edema in Brain Tumors. J. Intensiv. Care Med. 2017, 32, 15-24. [CrossRef]

39. Gold, A.; Eini, L.; Nissim-Rafinia, M.; Viner, R.; Ezer, S.; Erez, K.; Aqaqe, N.; Hanania, R.; Milyavsky, M.; Meshorer, E.; et al. Spironolactone inhibits the growth of cancer stem cells by impairing DNA damage response. Oncogene 2019, 38, 3103-3118. [CrossRef]

40. Alekseev, S.; Ayadi, M.; Brino, L.; Egly, J.M.; Larsen, A.K.; Coin, F. A small molecule screen identifies an inhibitor of DNA repair inducing the degradation of TFIIH and the chemosensitization of tumor cells to platinum. Chem. Biol. 2014, 21, 398-407. [CrossRef]

41. Shahar, O.D.; Kalousi, A.; Eini, L.; Fisher, B.; Weiss, A.; Darr, J.; Mazina, O.; Bramson, S.; Kupiec, M.; Eden, A.; et al. A high-throughput chemical screen with FDA approved drugs reveals that the antihypertensive drug Spironolactone impairs cancer cell survival by inhibiting homology directed repair. Nucleic Acids Res. 2014, 42, 5689-5701. [CrossRef]

42. Carnero, A.; Garcia-Mayea, Y.; Mir, C.; Lorente, J.; Rubio, I.T.; LLeonart, M.L. The cancer stem-cell signaling network and resistance to therapy. Cancer Treat. Rev. 2016, 49, 25-36. [CrossRef] 
43. Suzuki, S.; Yamamoto, M.; Sanomachi, T.; Togashi, K.; Sugai, A.; Seino, S.; Yoshioka, T.; Kitanaka, C.; Okada, M. Brexpiprazole, a Serotonin-Dopamine Activity Modulator, Can Sensitize Glioma Stem Cells to Osimertinib, a Third-Generation EGFR-TKI, via Survivin Reduction. Cancers 2019, 11, 947. [CrossRef]

44. Sanomachi, T.; Suzuki, S.; Togashi, K.; Seino, S.; Yoshioka, T.; Kitanaka, C.; Okada, M.; Yamamoto, M. Brexpiprazole Reduces Survivin and Reverses EGFR Tyrosine Kinase Inhibitor Resistance in Lung and Pancreatic Cancer. Anticancer Res. 2019, 39, 4817-4828. [CrossRef]

45. Suzuki, S.; Yamamoto, M.; Togashi, K.; Sanomachi, T.; Sugai, A.; Seino, S.; Yoshioka, T.; Kitanaka, C.; Okada, M. In vitro and in vivo anti-tumor effects of brexpiprazole, a newly-developed serotonin-dopamine activity modulator with an improved safety profile. Oncotarget 2019, 10, 3547-3558. [CrossRef]

46. Suzuki, S.; Okada, M.; Kuramoto, K.; Takeda, H.; Sakaki, H.; Watarai, H.; Sanomachi, T.; Seino, S.; Yoshioka, T.; Kitanaka, C. Aripiprazole, an Antipsychotic and Partial Dopamine Agonist, Inhibits Cancer Stem Cells and Reverses Chemoresistance. Anticancer Res. 2016, 36, 5153-5161. [CrossRef]

47. Ciccolini, J.; Serdjebi, C.; Peters, G.J.; Giovannetti, E. Pharmacokinetics and pharmacogenetics of Gemcitabine as a mainstay in adult and pediatric oncology: An EORTC-PAMM perspective. Cancer Chemother. Pharmacol. 2016, 78, 1-12. [CrossRef]

48. De Sousa Cavalcante, L.; Monteiro, G. Gemcitabine: Metabolism and molecular mechanisms of action, sensitivity and chemoresistance in pancreatic cancer. Eur. J. Pharmacol. 2014, 741, 8-16. [CrossRef]

49. Okamoto, K.; Okamoto, I.; Hatashita, E.; Kuwata, K.; Yamaguchi, H.; Kita, A.; Yamanaka, K.; Ono, M.; Nakagawa, K. Overcoming erlotinib resistance in EGFR mutation-positive non-small cell lung cancer cells by targeting survivin. Mol. Cancer Ther. 2012, 11, 204-213. [CrossRef]

50. Okamoto, K.; Okamoto, I.; Okamoto, W.; Tanaka, K.; Takezawa, K.; Kuwata, K.; Yamaguchi, H.; Nishio, K.; Nakagawa, K. Role of survivin in EGFR inhibitor-induced apoptosis in non-small cell lung cancers positive for EGFR mutations. Cancer Res. 2010, 70, 10402-10410. [CrossRef]

51. Morgillo, F.; Woo, J.K.; Kim, E.S.; Hong, W.K.; Lee, H.Y. Heterodimerization of insulin-like growth factor receptor/epidermal growth factor receptor and induction of survivin expression counteract the antitumor action of erlotinib. Cancer Res. 2006, 66, 10100-10111. [CrossRef]

52. Suzuki, S.; Okada, M.; Takeda, H.; Kuramoto, K.; Sanomachi, T.; Togashi, K.; Seino, S.; Yamamoto, M.; Yoshioka, T.; Kitanaka, C. Involvement of GLUT1-mediated glucose transport and metabolism in gefitinib resistance of non-small-cell lung cancer cells. Oncotarget 2018, 9, 32667-32679. [CrossRef]

53. Liu, Y.; Lear, T.; Iannone, O.; Shiva, S.; Corey, C.; Rajbhandari, S.; Jerome, J.; Chen, B.B.; Mallampalli, R.K. The Proapoptotic F-box Protein Fbxl7 Regulates Mitochondrial Function by Mediating the Ubiquitylation and Proteasomal Degradation of Survivin. J. Biol. Chem. 2015, 290, 11843-11852. [CrossRef]

54. Li, Z.; Pei, X.H.; Yan, J.; Yan, F.; Cappell, K.M.; Whitehurst, A.W.; Xiong, Y. CUL9 mediates the functions of the 3M complex and ubiquitylates survivin to maintain genome integrity. Mol. Cell 2014, 54, 805-819. [CrossRef]

55. Chen, H.; Yang, F.; Li, X.; Gong, Z.J.; Wang, L.W. Long noncoding RNA LNC473 inhibits the ubiquitination of survivin via association with USP9X and enhances cell proliferation and invasion in hepatocellular carcinoma cells. Biochem. Biophys. Res. Commun. 2018, 499, 702-710. [CrossRef]

56. Delyani, J.A.; Rocha, R.; Cook, C.S.; Tobert, D.S.; Levin, S.; Roniker, B.; Workman, D.L.; Sing, Y.L.; Whelihan, B. Eplerenone: A selective aldosterone receptor antagonist (SARA). Cardiovasc. Drug Rev. 2001, 19, 185-200. [CrossRef]

57. Fagart, J.; Hillisch, A.; Huyet, J.; Barfacker, L.; Fay, M.; Pleiss, U.; Pook, E.; Schafer, S.; Rafestin-Oblin, M.E.; Kolkhof, P. A new mode of mineralocorticoid receptor antagonism by a potent and selective nonsteroidal molecule. J. Biol. Chem. 2010, 285, 29932-29940. [CrossRef]

58. Kolkhof, P.; Barfacker, L. 30 YEARS OF THE MINERALOCORTICOID RECEPTOR: Mineralocorticoid receptor antagonists: 60 years of research and development. J. Endocrinol. 2017, 234, T125-T140. [CrossRef]

59. Nair, A.B.; Jacob, S. A simple practice guide for dose conversion between animals and human. J. Basic Clin. Pharm. 2016, 7, 27-31. [CrossRef]

60. Okada, M.; Shibuya, K.; Sato, A.; Seino, S.; Watanabe, E.; Suzuki, S.; Seino, M.; Kitanaka, C. Specific role of JNK in the maintenance of the tumor-initiating capacity of A549 human non-small cell lung cancer cells. Oncol. Rep. 2013, 30, 1957-1964. [CrossRef] 
61. Suzuki, S.; Okada, M.; Shibuya, K.; Seino, M.; Sato, A.; Takeda, H.; Seino, S.; Yoshioka, T.; Kitanaka, C. JNK suppression of chemotherapeutic agents-induced ROS confers chemoresistance on pancreatic cancer stem cells. Oncotarget 2015, 6, 458-470. [CrossRef]

62. Matsuda, K.; Sato, A.; Okada, M.; Shibuya, K.; Seino, S.; Suzuki, K.; Watanabe, E.; Narita, Y.; Shibui, S.; Kayama, T.; et al. Targeting JNK for therapeutic depletion of stem-like glioblastoma cells. Sci. Rep. 2012, 2, 516. [CrossRef] [PubMed]

63. Okada, M.; Takeda, H.; Sakaki, H.; Kuramoto, K.; Suzuki, S.; Sanomachi, T.; Togashi, K.; Seino, S.; Kitanaka, C. Repositioning CEP-1347, a chemical agent originally developed for the treatment of Parkinson's disease, as an anti-cancer stem cell drug. Oncotarget 2017, 8, 94872-94882. [CrossRef] [PubMed]

64. Sanomachi, T.; Suzuki, S.; Kuramoto, K.; Takeda, H.; Sakaki, H.; Togashi, K.; Seino, S.; Yoshioka, T.; Okada, M.; Kitanaka, C. Olanzapine, an Atypical Antipsychotic, Inhibits Survivin Expression and Sensitizes Cancer Cells to Chemotherapeutic Agents. Anticancer Res. 2017, 37, 6177-6188. [CrossRef] [PubMed]

65. Takeda, H.; Okada, M.; Kuramoto, K.; Suzuki, S.; Sakaki, H.; Sanomachi, T.; Seino, S.; Yoshioka, T.; Hirano, H.; Arita, K.; et al. Antitumor activity of gemcitabine against high-grade meningioma in vitro and in vivo. Oncotarget 2017, 8, 90996-91008. [CrossRef] [PubMed]

(C) 2019 by the authors. Licensee MDPI, Basel, Switzerland. This article is an open access article distributed under the terms and conditions of the Creative Commons Attribution (CC BY) license (http://creativecommons.org/licenses/by/4.0/). 